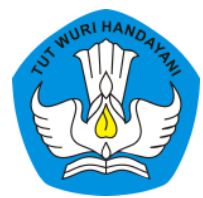

Page: 301-330

\title{
EFEKTIVITAS PROGRAM CATCH BERBASIS TUTOR SEBAYA DITINJAU DARI SELF-EFFICACY DAN KOMUNIKASI MATEMATIS SISWA
}

\author{
Setiana \\ Sekolah Menengah Pertama Darma Bangsa, Bandar Lampung, Lampung, Indonesia \\ Contributor Email: setiana_00200108@darmabangsa.sch.id
}

Received: Mar 9, 2021

Accepted: Jun 6, 2021

Published: Jul 30, 2021

Article Url: https:/ / ojsdikdas.kemdikbud.go.id/index.php/didaktika/article/view/171

\begin{abstract}
Self-efficacy and mathematics communication are problems associated with the CATCH program and are the subject of this research. The aim of this research is to know the effectiveness of CATCH program based on peer tutoring to self-efficacy and the students' mathematics communication. CATCH program is develop into some levels, those are pre development, development, and post development. The Research and Development methodology that is used the system of Akker, it consists of introductionand formativetest with Tessemer as the guidance. It measures: self evaluation; expert review; one to one; small group; field test. The subject of this research is the students of Junior High School with 20 students of Grade 8. The selfefficacy scoring is got from self-efficacy scale and the data of mathematics communication ability based on mathematics communication test. The expert review shows that CATCH program based on peer tutoring to fulfill the standard of material, design, and language. The result of one to one test shows the positive result based on the students' response after getting the program and the students' responsibility towards the program. Then, the test of small group shows the positive result of the reading efficiency and their understanding. The research shows that the CATCH program based on peer tutoring is the effective way to improve self-efficacy and the students mathematics communication.
\end{abstract}

Keywords: CATCH Program; Peer Tutoring; Self-Efficacy (SE); Mathematics Communication 


\begin{abstract}
Abstrak
Self-efficacy dan komunikasi matematis merupakan problematika yang dikaitkan dengan program CATCH dan menjadi bahasan dalam penelitian ini. Tujuan penelitian ini adalah untuk mengetahui efektivitas program CATCH berbasis tutor sebaya terhadap self-efficacy dan kemampuan komunikasi matematis siswa. Program CATCH yang dilakukan adalah prapengembangan, pengembangan, dan paska pengembangan. Metode penelitian dan pengembangan mengikuti alur Akker meliputi pendahuluan dan uji formatif, mengacu pada Tessemer mencakup: evaluasi diri; uji ahli; uji perorangan; uji kelas kecil; uji terbatas. Subjek penelitian pengembangan ini adalah siswa SMP berjumlah 20 siswa. Pengambilan skor self-efficacy dari skala selfefficacy dan data kemampuan komunikasi matematis melalui pemberian tes kemampuan komunikasi matematis. Hasil validasi ahli menunjukkan bahwa pengembangan program CATCH berbasis tutor sebaya memenuhi standar kelayakan materi, desain, dan bahasa. Hasil uji perorangan menunjukkan bahwa keterbacaan dan respon siswa terhadap program pada kategori sangat baik, dan uji kelas kecil menunjukkan efektivitas waktu membaca dan tingkat pemahaman pada kategori baik. Hasil penelitian menunjukkan bahwa program CATCH berbasis tutor sebaya efektif meningkatkan self-efficacy dan kemampuan komunikasi matematis siswa.
\end{abstract}

Kata Kunci: $\quad$ CATCH; Tutor Sebaya; Self-Efficacy (SE); Komunikasi Matematis

\title{
A. Pendahuluan
}

Permendiknas Nomor 22 Tahun 2006 menyebutkan bahwa peran matematika di segala bidang khususnya dalam perkembangan teknologi menuntut manusia untuk memiliki kemampuan yang kuat dalam matematika. Salah satu cara agar siswa memiliki kemampuan matematika yang kuat sejak dini adalah dengan cara meningkatkan proses pembelajaran. Untuk mendukung upaya tersebut, maka pemerintah Indonesia menyempurnakan kurikulum yang sesuai dengan tuntutan pembelajaran matematika yaitu Kurikulum 2013. Sebagaimana tercantum dalam Permendikbud Nomor 81A Tahun 2013, Kurikulum 2013 menggunakan pendekatan saintifik yang efektif apabila diterapkan pada pembelajaran matematika. Dalam Permendiknas Nomor 22 Tahun 2006 tentang Standar Isi, dijelaskan bahwa tujuan pembelajaran matematika adalah agar siswa memiliki kemampuan (1) memahami konsep matematika, (2) menggunakan 
penalaran matematis, (3) pemecahan masalah berkaitan dengan matematika, (4) mengomunikasikan secara matematis, dan (5) sikap menghargai kegunaan matematika. Keempat tujuan tersebut saling berkaitan dan mendukung satu sama lain.

Hasil temuan dari TIMSS (Trends International Mathematics and Science Study) pada tahun 2015 (Provasnik, 2016:5-9) menginformasikan bahwa pencapaian rata-rata matematika siswa di dunia menurun dari hasil TIMSS tahun 2011. Beberapa negara seperti Kuwait, Maroko, Saudi Arabia, Jordan, dan Indonesia merupakan negara-negara yang memperoleh pencapaian ratarata matematika terendah. Menurut Benchmark International, Indonesia berada ditingkat kelima dari bawah dengan capaian 397.

Kemampuan matematika siswa Indonesia berdasarkan capaiannya menunjukkan bahwa mereka memiliki sedikit dasar pengetahuan matematika, seperti penjumlahan, pengurangan, perkalian sederhana, pemecahan masalah matematika sederhana, mampu membaca grafik dan tabel sederhana, dan mampu menyajikan data sederhana dari tabel ke grafik batang dan piktogram. Berdasarkan uraian hasil TIMSS di atas, dapat dikatakan bahwa komunikasi matematis siswa di Indonesia masih rendah terbukti bahwa kemampuan menyajikan data ke dalam tabel dan grafik masih pada persoalan yang sederhana.

National Council of Teachers of Mathematics (NCTM) pada tahun 2000 menyatakan bahwa program pembelajaran matematika harus memberikan kesempatan seluas-luasnya kepada siswa untuk menyusun dan mengaitkan proses berpikir matematika, mengomunikasikan, menganalisis dan menilai, berpikir matematika, dan menggunakan bahasa matematis untuk mengekspresikan ide-ide matematika. Hulukati (2005) menyebutkan bahwa komunikasi matematis adalah syarat untuk dapat memecahkan masalah matematika. Artinya, jika siswa tidak dapat berkomunikasi dengan baik dalam memaknai permasalahan maupun konsep matematika maka ia tidak dapat menyelesaikan masalah tersebut dengan baik. Cara yang dilakukan agar siswa dapat menyampaikan ide atau gagasan mereka adalah 
melalui diskusi kelompok karena melalui kegiatan diskusi siswa mampu menyatakan, menjelaskan, menggambarkan, mendengar, menanyakan, dan bekerjasama sehingga dapat membawa siswa pada tingkat pemahaman matematika secara mendalam.

Selain itu, dapat dilakukan melalui kegiatan merancang suatu bentuk permasalahan berkaitan dengan proses penyelesaian permasalahan matematika dibutuhkan penjelasan, penalaran-penalaran, dan tidak sekadar jawaban akhir dari suatu prosedur yang baku (Karolina, et.al., 2020). Srianggoro (2004) menyebutkan bahwa kemampuan komunikasi matematis akan membuat seseorang bisa memanfaatkan matematika untuk kepentingan diri sendiri maupun orang lain, yang pada akhirnya dapat meningkatkan sikap positif terhadap matematika baik dari dalam diri sendiri maupun orang lain.

Sikap positif merupakan aspek afektif yang memiliki peran penting dalam belajar matematika contohnya self-efficacy (SE). Hal ini sesuai dengan penelitian yang dilakukan oleh Betz dan Hacket pada tahun 1983 (Pajares, 2002:11), dimana ditemukan fakta bahwa di beberapa negara termasuk Indonesia banyak siswa yang cepat bosan ketika diajari materi matematika. Akibatnya, motivasi mereka untuk mengerti dan menguasai matematika dengan sendirinya akan turun. Mereka menganggap bahwa matematika hanya sebagai suatu kewajiban untuk dipelajari karena tercantum dalam kurikulum, tanpa adanya penghargaan terhadap kegunaan matematika dalam kehidupan nyata. Selain itu pengalaman-pengalaman yang kurang menyenangkan juga dapat memengaruhi persepsi siswa terhadap pelajaran matematika (Badri, et.al., 2018).

Hal ini menyebabkan siswa menjadi enggan atau malas untuk mempelajari matematika gambaran mengenai peranan SE dalam pembelajaran matematika dapat dilihat ketika siswa mengalami situasi yang tidak menyenangkan seperti yang telah dipaparkan di atas, keyakinan siswa akan kemampuannya untuk mengorganisasikan dan 
mengontrol penggunaan kemampuan dan keterampilan mereka pada mata pelajaran matematika digunakan sebagai motivator sehingga siswa akan memperbesar usahanya agar dapat mencapai prestasi seperti yang diharapkan.

Semakin tinggi SE yang dimiliki individu, maka akan semakin tinggi pula motivasi individu tersebut untuk memperbesar usahanya agar mencapai hasil yang lebih optimal. Bandura (1997) juga mendefinisikan $S E$ sebagai pertimbangan seseorang mengenai kemampuan dirinya dalam rangka mencapai tingkatan kinerja yang diinginkan atau ditentukan, yang akan memengaruhi tindakan individu itu selanjutnya. Menurut Zulkosky (2009: 93-102) SE memengaruhi kehidupan seseorang dalam hal bagaimana orang berpikir, merasa, memotivasi diri, dan bertindak. Semakin tinggi SE yang dimiliki seorang siswa, akan semakin baik prestasi yang mampu dicapainya. Begitu juga sebaliknya, semakin rendah SE yang dimiliki seorang siswa, akan semakin rendah pula prestasi yang mampu dicapai siswa tersebut.

Berdasarkan hasil studi pendahuluan, peneliti tertarik untuk mengembangkan serta menerapkan sebuah strategi dalam rangka mengatasi permasalahan yang terjadi pada pembelajaran matematika di SMP Darma Bangsa. Ini merupakan program yang berkiblat pada penelitian Nguyen (2013) dari Duke University, yaitu program CATCH atau Caring About The Concepts that Help dengan beberapa pengembangan pada content dan tahap-tahap pelaksanaan kegiatannya akan menjadi fokus pada penelitian ini. Selain itu, tujuan yang ingin dicapai untuk menjangkau siswa yang berkemampuan heterogen dan pengembangan program $\mathrm{CATCH}$ pada penelitian ini akan memperluas tujuannya sesuai dengan hasil analisis SWOT, yaitu meningkatkan SE. Penyebabnya adalah adanya kemunduran keyakinan diri siswa terhadap kemampuannya dalam matematika yang sudah mulai terlihat di SMP yang menjadi subjek. Kemampuan komunikasi matematis sebagai salah satu aspek kognitif juga akan menjadi fokus dalam penelitian ini. 
Dengan fokus terhadap peningkatan kedua aspek tersebut diharapkan akan berdampak positif terhadap hasil belajar matematika siswa. Upaya meningkatkan kedua aspek melalui penerapan program CATCH dilakukan dengan berbasis tutor sebaya. Nguyen (2013) menyatakan bahwa tutor sebaya termasuk pembelajaran mandiri yang dapat memberikan pengaruh terhadap siswa, baik dari segi keterampilan akademik, SE, tanggung jawab, dan interaksi sosial. Roscoe dan Chi (2007), Ruseno dan Titin (2010) juga menyebutkan bahwa tutor sebaya merupakan sebuah metode yang mampu mengaktifkan siswa. Senada dengan pendapat Vygotsky, Danoebroto (2015) seorang ahli teori belajar konstruktivisme yang menyebutkan bahwa interaksi sosial dengan orang lain mendorong terbentuknya ide baru dan memperkaya perkembangan intelektual khususnya kognitif pembelajar.

Kaitannya dengan pembelajaran matematika, kemampuan matematika siswa akan berkembang melalui interaksinya dengan orang lain yang menguasai matematika lebih baik. Berdasarkan hal tersebut, Nguyen menciptakan program $\mathrm{CATCH}$ yang didesain untuk memasangkan siswa berkemampuan tinggi dengan rendah agar sukses dalam akademik, melalui supervisi guru.

Implementasi program $\mathrm{CATCH}$ ini dikaitkan dengan tutor sebaya yang memfokuskan pada permasalahan $S E$ dan komunikasi matematis siswa dalam pembelajaran matematika. Selain menghasilkan produk dari pengembangan program $\mathrm{CATCHberbasis} \mathrm{tutor} \mathrm{sebaya,} \mathrm{penelitian} \mathrm{ini}$ bertujuan untuk mengetahui tingkat efektivitas $S E$ dan kemampuan komunikasi matematis.

\section{B. Metode}

Penelitian ini adalah penelitian pengembangan yang mengacu pada metode penelitian dan pengembangan (Research and Development) yang mengikuti alur Akker (2006: 233) dengan 2 tahap yaitu pre-liminary (tahap pendahuluan) dan tahap prototyping (pembuatan produk) dengan 
langkah-langkah mengacu pada Tessemer (1993) melalui formative evaluation (uji formatif) yang meliputi self-evaluation (uji oleh diri sendiri), expert reviews (uji ahli), one-to-one (uji satu-satu), small group (uji kelas kecil) kemudian field test (uji terbatas). Produk yang dikembangkan berupa pengembangan program pembelajaran $\mathrm{CATCH}$ yang disusun berdasarkan karakteristik program $C A T C H$. Program ini berbasis tutor sebaya untuk menganalisa kaitan $S E$ dengan kemampuan komunikasi matematis siswa pada kelas subjek. Subjek yang dikenai pada saat observasi adalah siswa kelas Arcturus (VIII A) dan Sirius (VIII B). Subjek pada saat wawancara adalah siswa kelas VIII dan satu orang guru yang mengajar matematika di kelas VIII.

Prosedur penelitian dan pengembangan difokuskan pada 2 tahap. Tahap pertama, Tahap Pendahuluan. Tahap ini terdiri dari tahap pengumpulan data dan tahap pendesainan. Pada tahap pengumpulan data dilakukan melalui observasi dan wawancara. Observasi dilakukan terhadap proses pembelajaran oleh guru matematika di kelas VIII. Wawancara dilakukan terhadap guru matematika dan siswa. Tahap pendesainan program $\mathrm{CATCH}$ dikembangkan berdasarkan karakteristik tutor sebaya, dan data-data diperoleh dari hasil observasi dan wawancara. Produk yang telah didesain pada tahap ini dinamakan prototype 1. Desain pada program $\mathrm{CATCH}$ terdapat pada tahap caring about, the concepts, dan helps.

Pada tahap carry, dilakukan dengan observasi terhadap perilaku siswa dalam mengikuti pembelajaran matematika, wawancara terhadap siswa, pemberian angket $S E$ untuk mengetahui tingkat keyakinan diri siswa terhadap pembelajaran matematika. Tahap the concepts, dilakukan dengan memberikan tes materi yang telah diajarkan oleh guru matematika dengan materi yang telah diajarkan oleh guru matematika kelas VIII yang disusun bersama-sama dengan peneliti, dengan maksud untuk menentukan indikator-indikator komunikasi matematisnya. Hasil tes ini digunakan oleh untuk menyeleksi siswa yang menjadi tutor. Pada 
tahap helps, diberikan modul yang disusun sesuai dengan karakteristik tutor sebaya dalam pembelajaran materi fungsi oleh peneliti terhadap kelas yang menjadi subjek. Selama kegiatan tutor sebaya berlangsung, guru melakukan pengawasan dan memberikan penguatan kepada tutor dan tutee. Produk yang dihasilkan pada tahap ini disebut prototype 1.

Tahap kedua, uji formatif. Tahap ini mengikuti alur Tessemer (1993: 15) terdiri dari evaluasi diri, uji ahli, uji perorangan, uji kelas kecil, dan uji terbatas. Pada tahap evaluasi diri dilakukan penilaian diri terhadap hasil desain prototype 1 program $\mathrm{CATCH}$ berbasis tutor sebaya dengan modul yang berdasarkan kelayakan materi, desain, dan bahasa. Uji ahli dilakukan dengan menyerahkan Prototype 1 kepada ahli materi, desain, dan bahasa untuk divalidasi. Hasil validasi dari ahli yaitu Prototype 1, diuji cobakan pada 6 orang siswa kelas VIIIA yang 2 siswa berkemampuan tinggi, 2 siswa berkemampuan sedang, dan 2 siswa berkemampuan rendah. Pada kegiatan ini, diberikan pembelajaran menggunakan program $\mathrm{CATCH}$ dan diakhir kegiatan siswa yang menjadi subjek di tahap ini diberi lembar skala untuk mengukur keterbacaan dan respon terhadap program $\mathrm{CATCH}$.

Selain itu, di akhir tiap pertemuan, siswa yang menjadi subjek di tahap ini diwawancarai mengenai isi modul berbasis tutor sebaya. Masukannya dijadikan bahan perbaikan modul. Hasil pengamatan pada tahap ini untuk merevisi prototype 1, hasilnya sebagai prototype 2. Pada tahap uji kelas kecil,prototype 2 diujicobakan pada 12 siswa dari kelas VIII A yang belum memperoleh materi fungsi dengan 4 siswa berkemampuan tinggi, 4 siswa berkemampuan sedang, dan 4 siswa berkemampuan rendah. Pada tahap ini, diadakan pengukuran mengenai efisiensi waktu membaca materi pada modul dan tingkat pemahaman siswa dengan mengerjakan soal-soal pada uji kompetensi. Hasil tahap ini digunakan untuk merevisi prototype 2, hasilnya sebagai prototype 3. Uji terbatas program $\mathrm{CATCH}$ berbasis tutor sebaya dengan modul dilakukan untuk 
mengetahui peningkatan $S E$ dan kemampuan komunikasi matematis siswa. Uji terbatas ini akan dilakukan di kelas VIII B.

Diawal dan akhir pembelajaran, siswa diberi tes kemampuan komunikasi matematis dan skala SE untuk mengetahui efektivitas pembelajaran dengan menggunakan pengembangan program $\mathrm{CATCH}$. Secara prosedural, penelitian pengembangan ini dapat dilihat pada Gambar. 1.

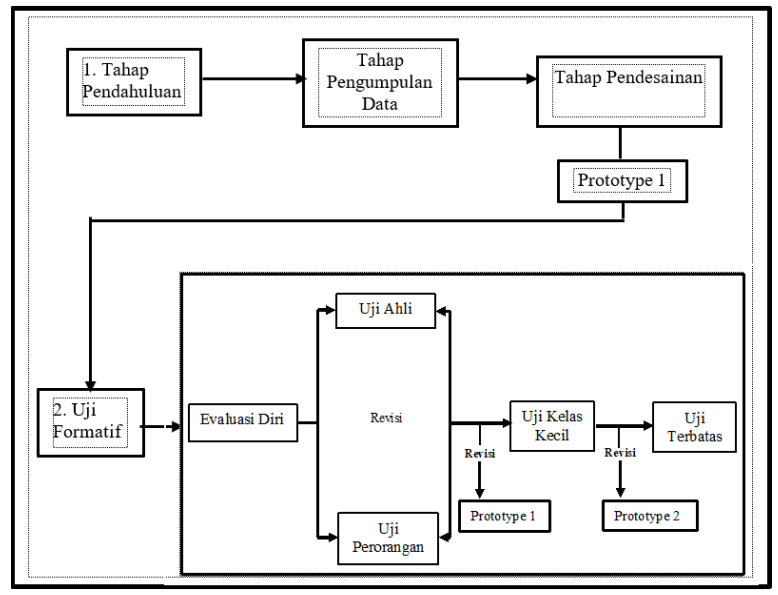

Gambar 1. Prosedur Penelitian

Instrumen penelitian yang digunakan adalah non tes dan tes yang diberikan sesuai dengan subjek pada penelitian pengembangan. Instrumen pada studi pendahuluan adalah non tes berupa lembar observasi dan wawancara. Validasi program $C A T C H$ diserahkan kepada ahli materi, ahli desain, dan ahli bahasa dengan instrumen berupa skala Likert dengan empat pilihan jawaban (Sangat Baik, Baik, Cukup Baik, Kurang Baik). Pada uji perorangan diberikan instrumen non tes berupa angket keterbacaan dan tanggapan terhadap program $\mathrm{CATCH}$ berbasis tutor sebaya. Instrumen yang digunakan pada uji kelas kecil adalah non test berupa lembar angket efisiensi waktu membaca materi pada modul. Uji terbatas menggunakan instrumen test berupa pretest dan posttest untuk mengukur kemampuan komunikasi matematis. Instrumen non test pada uji terbatas dilakukan untuk melihat SE siswa sebelum dan sesudah 
mendapatkan pembelajaran dengan program $\mathrm{CATCH}$ yang telah dikembangkan dan diukur menggunakan skala Likert.

Teknik pengumpulan data yang digunakan pada penelitian ini dijelaskan berdasarkan jenis instrumen, yaitu (1) Analisis data studi pendahuluan. Teknik yang digunakan berupa observasi dan wawancara menggunakan angket siswa, angket pelaksanaan program $\mathrm{CATCH}$ berbasis tutor sebaya, dan angket pengukuran tingkat SE; (2) Tes. Teknik ini berupa pretest, posttest, dan tes komunikasi matematis yang bertujuan untuk mengetahui kemampuan siswa dalam merepresentasikan permasalahan, proses penyelesaian, dan menemukan jawaban; (3) Observasi. Teknik ini dilakukan oleh observer yaitu guru lain untuk mengamati proses pembelajaran matematika; (4) Wawancara. Kegiatan ini dikenakan kepada guru matematika dan siswa kelas VIII.

Teknik analisis data pada penelitian ini dijelaskan berdasarkan instrumen yang digunakan dalam setiap tahapan penelitian pengembangan, yaitu (1) Analisis data studi pendahuluan. Data berupa observasi dan wawancara yang dianalisis secara deskriptif sebagai latar belakang diperlukannya program $\mathrm{CATCH}$ berbasis tutor sebaya; (2) Analisis data kelayakan. Data yang diperoleh berupa hasil penilaian validator melalui skala kelayakan yang dianalisis dalam bentuk deskriptif kuantitatif dan kualitatif sebagai acuan untuk memperbaiki program CATCH berbasis tutor sebaya. Data kuantitatif yang berupa skor penilaian ahli materi dan ahli desain dideskripsikan secara kuantitatif, kemudian dijelaskan secara kualitatif. Teknik analisa data yang digunakan untuk menganalisa data hasil penilaian kelayakan adalah teknik analisis deskriptif; (3) Analisis data uji perorangan dan kelas kecil. Teknik yang dilakukan berupa analisa lembar skala yang diberikan pada siswa untuk mengukur tingkat keterbacaan dalam memahami modul berbasis tutor sebaya. Skala yang digunakan adalah skala Likert. Analisis uji kelas kecil dilakukan dengan menganalisis secara deskriptif terhadap lembar alokasi waktu membaca; (4) Analisis data uji terbatas. Data yang diperoleh pada 
uji ini adalah data $S E$ dan kemampuan komunikasi matematis yang diukur dengan menggunakan skala Likert. Hasil analisis data SE diperkuat dengan melakukan uji statistik parametrik berupa uji $\mathrm{t}$ berpasangan (Paired Sample t test), dikarenakan data skor SE berdistribusi normal. Kesimpulan hasil uji normalitas data skor $S E$ siswa sebelum dan sesudah dilakukan pembelajaran program $\mathrm{CATCH}$ dengan menggunakan uji normalitas Kolmogorv Smirnov dapat dilihat pada Tabel B.1.

Tabel. B.1. Hasil Uji NormalitasSE

\begin{tabular}{ccccc}
$\begin{array}{c}\text { Banyak } \\
\text { Siswa }\end{array}$ & \multicolumn{2}{c}{ Nilai Signifikan } & $\propto$ & Kategori \\
\hline 20 & 0,248 & 0,704 & 0,05 & Normal
\end{tabular}

Pada tabel di atas, nilai signifikan kedua data skor $S E$ lebih dari 0,05 (nilai signifikan data skor pretest adalah 0,248 > 0,05 dan nilai signifikan data skor posttest adalah $0,704>0,05$ ) yang berarti kedua data skor SE berdistribusi normal. Uji $t$ pada penelitian ini dengan menggunakan Paired Samples Test, dengan signifikansi, $p=0.000$ dan tingkat kepercayaan $95 \%$ maka $\mathrm{p}<0.05$. Hipotesis penelitiannya adalah: (1) Ho, tidak ada perbedaan rata-rata skor pretest dan posttest dan (2) $\mathrm{H}_{1}$, ada perbedaan rata-rata skor pretest dan posttest.

Data analisis data kemampuan komunikasi matematis diperoleh dengan cara memberikan pretest dan postttest. Besarnya peningkatan kemampuan komunikasi matematis diukur dengan menghitung N-Gain. Hasil analisis deskriptif ini diperkuat dengan melakukan uji statistik parametrik berupa uji $\mathrm{t}$ berpasangan. Berikut ini adalah hasil uji normalitas data skor kemampuan komunikasi matematis siswa sebelum dan sesudah dilakukan program $\mathrm{CATCH}$ dengan menggunakan uji normalitas Kolmogorov Smirnov.

Tabel B.2. Hasil Uji Normalitas Kemampuan Komunikasi Matematis

\begin{tabular}{ccccc} 
Banyak & \multicolumn{2}{c}{ Nilai Signifikan } & $\propto$ & Kategori \\
\hline Siswa & Pretest & Posttest & & \\
\hline 20 & 0,295 & 0,339 & 0,05 & Normal
\end{tabular}


Berdasarkan Tabel B.2. diperoleh nilai signifikan kedua data skor kemampuan komunikasi matematis lebih dari 0,05 (nilai signifikan data pretest adalah 0,295 > 0,05 dan nilai signifikan data posttest adalah 0,339> $0,05)$ yang berartikedua data skor kemampuan komunikasi matematis berdistribusi normal. Berdasarkan hasil tersebut maka pengujian dilakukan secara parametrik yaitu dengan menggunakan uji $t$ berpasangan dengan signifikansi, $\mathrm{p}=0,000$ dan tingkat kepercayaan 95\% maka $\mathrm{p}<0,05$. Hipotesis penelitiannya, yaitu: (1) Ho, tidak ada perbedaan rata-rata skor pretest dan posttest dan (2) $\mathrm{H}_{1}$, ada perbedaan rata-rata skor pretest dan posttest.

\section{Hasil dan Pembahasan}

Hasil penelitian ini meliputi deskripsi program $\mathrm{CATCH}$ berbasis tutor sebaya, deskripsi $S E$ siswa yang diberikan program $C A T C H$ berbasis tutor sebaya, dan deskripsi kemampuan komunikasi matematis siswa yang diberikan program $\mathrm{CATCH}$ berbasis tutor sebaya, dipaparkan sebagai berikut:

\section{Hasil}

\section{Deskripsi Pelaksanaan Program $\mathrm{CATCH}$ Berbasis Tutor Sebaya}

Pelaksanaan program $\mathrm{CATCH}$ melalui beberapa tahap, meliputi tahap pendahuluan dan tahap uji formatif. Pada tahap pendahuluan terdiri dari pengumpulan data dan desain produk. Pada pengumpalan data dilakukan dengan observasi pembelajaran dan wawancara terhadap guru, serta pemberian angket pertanyaan kepada siswa mengenai tanggapan terhadap pembelajaran matematika. Hasil observasi menunjukkan bahwa siswa kurang antusias ketika guru meminta untuk membaca materi, dibandingkan ketika guru yang menjelaskan. Kemampuan komunikasi matematis ditunjukkan ketika siswa menjawab secara lisan maupun tertulis, namun masih tergolong rendah. Berdasarkan hasil observasi terlihat bahwa siswa kesulitan memahami soal akibatnya kesulitan dalam menuliskan jawaban apalagi jika terdapat 
simbol-simbol matematika. Hasil wawancara menunjukkan bahwa terdapat kendala dalam penggunaan buku teks K-13 khususnya pada pemahaman siswa terhadap soal-soal kontekstual. Hasil wawancara dengan guru matematika menunjukkan bahwa pada materi sistem koordinat siswa yang tuntas sebanyak $25,9 \%$ dan $74,1 \%$ adalah siswa yang tidak tuntas. Karakteristik pembelajaran yang digunakan guru sudah mencakup indikator kemampuan komunikasi matematis, namun masih pada indikator 1 dan 2. Desain produk ini meliputi desain pengembangan program $\mathrm{CATCH}$ berbasis tutor sebaya dan desain modul berbasis tutor sebaya.

Desain produk pengembangan program $\mathrm{CATCH}$ berbasis tutor sebaya meliputi tiga tahap yaitu(1) prapengembangan, hasil pada tahap ini berupa terpilihnya tutor berdasarkan kriteria kemampuan akademik tinggi yang dibuktikan dengan hasil belajar semester genap kelas VII, mampu berkomunikasi, memiliki empati, dan kemampuan interpersonal yang baik yang ditunjukkan pada hasil observasi; (2) pengembangan, yang meliputi kegiatan caring about, concept, dan help. Caring about dilakukan melalui pendekatan observasi dan wawancara terhadap siswa yang mewakili siswa berkemampuan tinggi, sedang, dan rendah pada kelas subjek sebelum pembelajaran materi fungsi. Hasil kegiatan ini menunjukkan bahwa diperlukan metode pembelajaran yang mampu menumbuhkan keaktifan seluruh siswa tidak hanya siswa yang berkemampuan akademik tinggi dan sedang, siswa berkemampuan rendah mengalami kendala dalam memahami materi khususnya dalam mengerjakan soal hitungan. Hasil dari kegiatan concept yang meliputi pemasangan tutor dan tutee, pembinaan tutor dan tutee, pendampingan berkala terhadap tutor dan penguatan partisipan yaitu strategi pemasangan tutor dan tutee dibebaskan pada tutee untuk memilih tutornya sehingga proses interaksi terjadi dengan baik dan berdampak positif pada komunikasi matematis yang baik. Help yang merupakan kegiatan terakhir pada tahap pengembangan program $\mathrm{CATCH}$ yang meliputi bimbingan, perbaikan, dan pembinaan, seperti pada Tabel C.1. 
Secara umum, hasil observasi menyebutkan bahwa metode tutor sebaya sangat cocok digunakan karena siswa yang menjadi tutor telah menguasai konsep sehingga dapat membantu tutee dalam memahami materi dengan cara mereka sendiri. Selain itu, siswa yang menjadi tutee terlihat percaya diri untuk bertanya. Namun, guru harus selalu melakukan pendampingan agar tidak terjadi kesalahan dalam penyampaian materi oleh tutor. (3) Pasca pengembangan merupakan tahap ketiga dengan memberikan penguatan berupa tes kemampuan komunikasi matematis siswa dan angket $S E$.

Uji formatif merupakan tahapk edua yang terdiri dari beberapa tahap yaitu (1) Evaluasi diri. Pada tahap ini dilakukan pengecekan kemudian dievaluasi kembali oleh ahli. (2) Uji ahli. Validasi terhadap program $\mathrm{CATCH}$ berbasis tutor sebaya dilakukan di tahap ini oleh ahli materi, ahli desain, dan ahli bahasa. Hasil validasi ahli materi menunjukkan bahwa keempat komponennya itu kesesuaian materi dengan $\mathrm{KI}$ dan KD, keakuratan materi, kemutakhiran materi, dan mendorong keingintahuan, mendapat skor sangat baik yaitu 58 atau 90,63\% dari skor ideal 64. Meskipun hasil tersebut menunjukkan bahwa modul dapat digunakan, beberapa saran dan pendapat dari ahli materi dijadikan sebagai bahan revisi. Aspek yang dinilai pada uji validasi ahli desain adalah program $\mathrm{CATCH}$ dan modul. Hasil dari validasi program $\mathrm{CATCH}$ menunjukkan bahwa program $\mathrm{CATCH}$ dapat digunakan namun perlu direvisi yaitu perlu adanya tambahan deskripsi dari peneliti terdahulu yaitu Nguyen (2013). Uji kelayakan program CATCH dapat dilihat di Tabel C.1.

Tabel C.1. Hasil Uji Kelayakan Desain Program CATCH AspekKelayakan Jumlah Total Jumlah Skor Total

\begin{tabular}{lcc}
\multicolumn{1}{c}{ AspekKelayakan } & Jumlah Total & Jumlah Skor Total \\
\hline Landasan Pemikiran & 6 & 8 \\
Rasionalitas & 3 & 4 \\
Kelengkapan Suplemen & 3 & 8 \\
Pelaksanaan Program & 15 & 20 \\
Penutup & 9 & 12 \\
Total & 43 & 52 \\
Kategori Penilaian & \multicolumn{2}{c}{ Sangat Baik }
\end{tabular}


Hasil validasi modul menyebutkan supaya kegiatan didasarkan pada pendekatan scientific, mengingat subjek berasal dari sekolah yang menerapkan K-13. Sedangkan hasil uji kelayakan seperti yang ditunjukkan di Tabel C.2, menunjukkan bahwa modul perlu direvisi sebelum digunakan pada uji perorangan.

Tabel C.2. Hasil Uji Kelayakan Desain Modul

\begin{tabular}{|c|c|c|}
\hline $\begin{array}{l}\text { Aspek Kelayakan } \\
\text { Desain Modul }\end{array}$ & Jumlah Total & $\begin{array}{c}\text { Jumlah Skor } \\
\text { Total }\end{array}$ \\
\hline Ukuran Modul & 8 & 8 \\
\hline Desain Modul & 93 & 108 \\
\hline Total & 95 & 116 \\
\hline Kategori Penilaian & \multicolumn{2}{|c|}{ Baik } \\
\hline
\end{tabular}

Uji validasi oleh ahli bahasa menunjukkan hasil yang baik yaitu 40 atau $83,33 \%$ pada seluruh aspek uji kelayakan bahasa yang digunakan pada modul, seperti ditunjukkan pada Tabel C.3.

Tabel C.3. Hasil Uji Ahli Bahasa terhadap Modul

\begin{tabular}{lcc}
\multicolumn{1}{c}{$\begin{array}{c}\text { Indikator Uji Kelayakan } \\
\text { Bahasa Modul }\end{array}$} & $\begin{array}{c}\text { Jumlah } \\
\text { Total }\end{array}$ & $\begin{array}{c}\text { Jumlah Skor } \\
\text { Total }\end{array}$ \\
\hline Lugas & 10 & 12 \\
Komunikatif & 3 & 4 \\
Dialogis dan Interaktif & 8 & 8 \\
Kesesuaian dengan Perkembangan & 6 & 8 \\
Siswa & 7 & 8 \\
Kesesuaian dengan Kaidah Bahasa & 6 & 8 \\
Penggunaan Istilah, Simbol atau Ikon & 40 & 46 \\
Total & \multicolumn{2}{c}{ Sangat Baik } \\
Kategori Penilaian & \multicolumn{2}{c}{. }
\end{tabular}

Ahli juga memberikan saran dan pendapat sebagai bahan revisi, yaitu modul harus ditambahkan gambar yang sesuai dengan masalah yang diberikan serta penggunaan bahasa yang komunikatif harus diperbanyak supaya siswa lebih mudah paham. Hal ini dimaksudkan untuk membantu 
siswa dalam meningkatkan daya imajinasinya, khususnya jika siswa berhadapan dengan soal-soal yang berkaitan dengan kehidupan nyata.

Hasil uji validasi angket $S E$ yang dilakukan oleh psikolog terbukti valid setelah melalui pengujian seperti disajikan pada Tabel C.4. Terlihat bahwa seluruh item pertanyaan dalam angket variabel $S E$ telah dianggap valid oleh para ahli. Hal ini dikarenakan seluruh item dapat menjelaskan variabel SE. Dengan demikian, seluruh item pertanyaan tersebut digunakan dalam mengukur variabel $S E$.

Tabel C.4. Hasil Uji Validitas Ahli Seluruh

Item Pertanyaan dalam Variabel SE

\begin{tabular}{lcl} 
Aspek yang dinilai & No Item & Keterangan \\
\hline \multirow{2}{*}{ Pencapaian Kinerja } & 4 & Sangat Valid \\
& 5 & Sangat Valid \\
& 11 & Sangat Valid \\
& 12 & Sangat Valid \\
& 13 & Valid \\
Pengalaman Orang Lain & 15 & Vangat Valid \\
& 17 & Valid \\
& 20 & Sangat Valid \\
Persuasi Verbal & 3 & Sangat Valid \\
& 1 & Sangat Valid \\
& 10 & Sangat Valid \\
& 14 & Sangat Valid \\
& 16 & Valid \\
& 7 & Valid \\
& 9 & Sangat Valid \\
& 19 &
\end{tabular}


Uji one to one. Uji ini diuji cobakan kepada 6 siswa dengan kemampuan heterogen yang belum menempuh materi. Uji ini dilakukan untuk mengetahui keterbacaan dan respon siswa terhadap program. Hasil uji keterbacaan siswa terhadap program $C A T C H$ berbasis tutor sebaya menunjukkan skor 69,67, kategori sangat baik, seperti yang ditunjukkan pada Tabel C.5.

Tabel C.5. Hasil Uji Keterbacaan Program CATCH Berbasis Tutor Sebaya

\begin{tabular}{ccc} 
Responden & $\begin{array}{c}\text { Jumlah Total Skor } \\
\text { yang Diberikan }\end{array}$ & Kategori Penilaian \\
\hline R1 & 67 & Sangat Baik \\
R2 & 76 & Sangat Baik \\
R3 & 72 & Sangat Baik \\
R4 & 69 & Sangat Baik \\
R5 & 64 & Baik \\
R6 & 70 & Sangat Baik \\
Rata-Rata & 69,67 & Sangat Baik
\end{tabular}

Uji small group. Uji ini dikenakan pada 12 siswa dengan kemampuan heterogen untuk mengukur efektivitas waktu membaca materi dalam modul. Hasil uji pengukuran waktu membaca seperti pada diagram 2 menunjukkan bahwa rata-rata lama siswa membaca adalah 8,51 menit, termasuk dalam kategori baik.

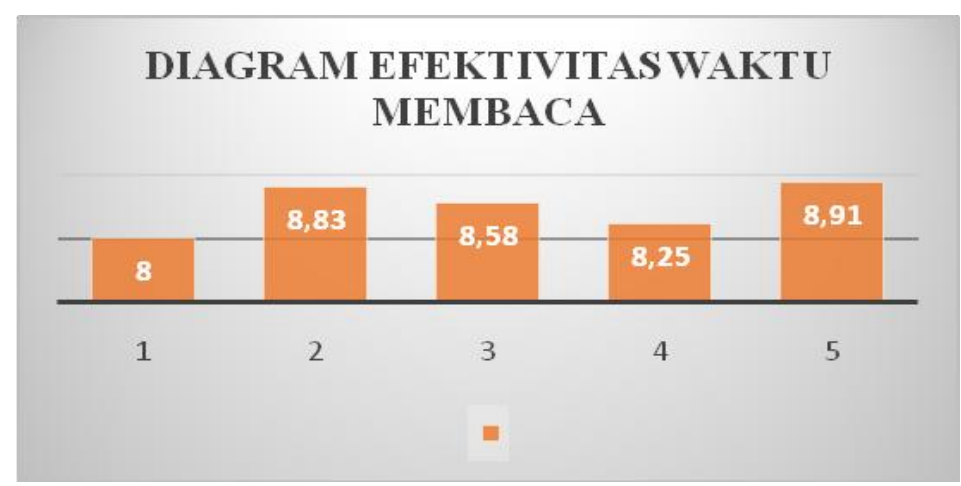

Diagram 1. Hasil Uji Kelas Kecil 
Pengukuran tingkat pemahaman siswa juga dilakukan pada tahap ini, dengan mengerjakan soal-soal uji kompetensi yang terdapat pada modul. Pengukuran tingkat pemahaman dilakukan setelah siswa selesai membaca modul. Hasil pengukuran tingkat pemahaman diperoleh rata-rata total 40,75 dengan rata-rata tertinggi adalah 0,82 , terendah adalah 0,51 dan berdasarkan $K K M \geq 76,00$ terdapat 6 siswa yang tuntas, 6 siswa tidak tuntas.

Uji terbatas. Pada uji terbatas dilakukan diuji keefektivitasan program $\mathrm{CATCH}$ berbasis tutor sebaya terhadap SE dan komunikasi matematis siswa. Sasarannya adalah kelas VIII yang berjumlah 20 siswa, 10 siswa sebagai tutor dan 10 siswa sebagai tutee. Tutor dan tutee akan berpasangan, sehingga membentuk 10 pasang siswa.

\section{Deskripsi Keefektivitasan Program CATCH Berbasis Tutor Sebaya terhadap $S E$}

Hasil pengukuran skala SE dengan pretest dan posttest menggunakan perhitungan N-Gain menurut Hake (1999). Hasil perhitungan N-Gain SE dapat dilihat pada Tabel C.6. Berdasarkan tabel tersebut, diketahui bahwa nilai rata-rata $N$-Gain adalah 0,71 . Nilai $0,71>0,70$ yang secara deskriptif menunjukkan peningkatan $S E$. Peningkatan ini tergolong tinggi sehingga dapat dikatakan bahwa penggunaan program $\mathrm{CATCH}$ adalah efektif dalam meningkatkan SE siswa.

Tabel C.6 Hasil PerhitunganN-Gain SE

\begin{tabular}{ccccc} 
No & Pretest & $\begin{array}{c}\text { Rata-Rata } \\
\text { Posttest }\end{array}$ & N-Gain & $\begin{array}{c}\text { Tingkat } \\
\text { Efektivitas }\end{array}$ \\
\hline 20 & 55,90 & 73,10 & 0,70 & Sangat Efektif
\end{tabular}

Hasil analisis deskriptif ini diperkuat dengan melakukan uji statistik parametrik berupa uji $\mathrm{t}$ berpasangan. Berdasarkan hasil penghitungan diperoleh tiga tabel, tabel pertama yaitu tabel Paired Samples Statistics dan diperoleh bahwa terjadi perbedaan rata-rata antara nilai $S E$ siswa sebelum (pretest) dan nilai $S E$ sesudah (posttest) yaitu dengan nilai rata-rata pretest 
55,90 dan nilai rata-rata posttest 73,10. Artinya, terjadi peningkatan $S E$ setelah digunakan program $\mathrm{CATCH}$ berbasis tutor sebaya. Dari tabel kedua yaitu paired samples correlation, didapatkan angka korelasi antara kedua variabel yaitu 0,167 dengan signifikansi sebesar 0,481. Setelah didapatkan angka korelasi dan dilakukan program $\mathrm{CATCH}$ yaitu 0,000. Dilihat dari rata-rata $N$ Gain skor pretest dan posttest SE yang diperkuat uji t, dapat disimpulkan bahwa pengembangan program $\mathrm{CATCH}$ berbasis tutor sebaya pada materi fungsi dapat meningkatkan $S E$ siswa dengan kategori sangat efektif.

\section{Deskripsi keefektivitasan program $C A T C H$ berbasis tutor sebaya terhadap komunikasi matematis siswa}

Pengukuran kemampuan komunikasi matematis dilakukan dengan pretest dan posttest. Data hasilnya digunakan untuk menganalisis pencapaian indikator komunikasi matematis siswa sebelum dan sesudah pembelajaran dengan program $\mathrm{CATCH}$ berbasis tutor sebaya diberikan. Hasil analisis pencapaian indikator komunikasi matematis siswa sebelum pembelajaran dengan program $C A T C H$ berbasis tutor sebaya disajikan pada Tabel C.7.

Tabel C.7. Data Pencapaian Indikator Kemampuan Komunikasi Matematis Siswa sebelum Pembelajaran

\begin{tabular}{|c|l|c|}
\hline No & \multicolumn{1}{|c|}{ Indikator } & $\begin{array}{c}\text { Persentase } \\
\text { Pencapaian }\end{array}$ \\
\hline 1 & $\begin{array}{l}\text { Menulis } \\
\text { Menjelaskan ide, situasi, dan relasi } \\
\text { matematika secara tertulis }\end{array}$ & $64,06 \%$ \\
2 & $\begin{array}{l}\text { Menggambar } \\
\text { Menggambarkan situasi masalah } \\
\text { dan menyatakan solusi masalah } \\
\text { menggunakan gambar }\end{array}$ & $27,50 \%$ \\
\hline 3 & $\begin{array}{l}\text { Ekspresi Matematis } \\
\text { Menggunakan bahasa matematika } \\
\text { secara tepat }\end{array}$ & $22,67 \%$ \\
\hline \multicolumn{2}{|c|}{ Rata-rata } & $\mathbf{3 8 , 0 8 \%}$ \\
\hline
\end{tabular}

Berdasarkan Tabel C.7. diketahui bahwa rata-rata persentase pencapaian indikator kemampuan awal komunikasi matematis siswa 
masih sangat rendah dengan rata-rata 38,08\%. Menulis merupakan indikator paling baik yang dicapai oleh siswa yaitu $64,06 \%$. Sedangkan hasil analisis pencapaian indikator komunikasi matematis siswa sesudah pembelajaran dengan program $\mathrm{CATCH}$ berbasis tutor sebaya disajikan pada Tabel C.8.

Tabel C.8. Data Pencapaian Indikator Kemampuan Komunikasi Matematis sesudah Pembelajaran

\begin{tabular}{|c|l|c|}
\hline No & \multicolumn{1}{|c|}{ Indikator } & $\begin{array}{c}\text { Persentase } \\
\text { Pencapaian }\end{array}$ \\
\hline 1 & $\begin{array}{l}\text { Menulis } \\
\text { Menjelaskan ide, situasi, dan relasi } \\
\text { matematika secara tertulis }\end{array}$ & $85,30 \%$ \\
\hline 2 & $\begin{array}{l}\text { Menggambar } \\
\text { Menggambarkan situasi masalah dan } \\
\text { menyatakan solusi masalah } \\
\text { menggunakan gambar }\end{array}$ & $97,50 \%$ \\
\hline 3 & $\begin{array}{l}\text { Ekspresi Matematis } \\
\text { Menggunakan bahasa matematika } \\
\text { secara tepat }\end{array}$ & $\mathbf{2}$ \\
\hline \multicolumn{2}{|c|}{ Rata-rata } \\
\hline
\end{tabular}

Deskripsi tabel di atas menunjukkan rata-rata pencapaian indikator kemampuan komunikasi matematis siswa sesudah pembelajaran adalah $89,40 \%$. Pencapaian indikator paling baik adalah indikator menggambar yaitu $97,50 \%$. Pencapaian indikator paling rendah adalah menulis yaitu 85,30\%. Data akhir kemampuan komunikasi matematis siswa dilakukan dengan cara melihat N-Gain, seperti yang disajikan pada Tabel C.9.

Tabel C.9. Hasil Perhitungan Rata-rata N-Gain Komunikasi Matematis

\begin{tabular}{|c|c|c|c|c|}
\hline \multirow{2}{*}{ No } & \multicolumn{3}{|c|}{ Rata-rata } & $\begin{array}{c}\text { Tingkat } \\
\text { Efektivitas }\end{array}$ \\
\cline { 2 - 4 } & Pretest & Postest & N-Gain & Sangat Efektif \\
\hline 20 & 12,55 & 29,75 & 0,85 & . \\
\hline
\end{tabular}

Berdasarkan tabel di atas, diketahui bahwa nilai rata-rata $N$-Gain adalah 0,85 , artinya secara deskriptif terjadi peningkatan kemampuan komunikasi matematis siswa yang tergolong tinggi dengan kata lain penggunaan program $\mathrm{CATCH}$ adalah sangat efektif dalam meningkatkan kemampuan komunikasi matematis siswa. 
Hasil analisis deskriptif ini diperkuat dengan melakukan uji statistic parametric berupa uji $\mathrm{t}$ berpasangan. Berdasarkan hasil penghitungan didapatkan tiga tabel. Tabel pertama yaitu tabel Paired Samples Statistics menunjukkan bahwa terjadi perbedaan rata-rata antara nilai kemampuan komunikasi matematis siswa sebelum (pretest) dan sesudah (posttest) diberikan program $\mathrm{CATCH}$. Sesudah diberikan program $\mathrm{CATCH}$ nilai rata rata pretest 12,55 dan posttest 29,75 . Artinya bahwa terjadi peningkatan kemampuan komunikasi matematis siswa setelah dikenai program $\mathrm{CATCH}$ berbasis tutor sebaya. Selanjutnya tabel kedua yaitu paired samples correlation didapatkan angka korelasi antara kedua variabel yaitu 0,557 dengan signifikansi sebesar 0,011 kemudian didapatkan nilai t hitung pada tabel ketiga yaitu pired samples test. Berdasarkan tabel tersebut dapat diketahui bahwa t hitung yang dihasilkan adalah $-16,184$ dengan signifikansi, $\mathrm{p}=0.000$ dan tingkat kepercayaan 95\%, maka $p<0,05$, sehingga Ho ditolak sehingga peningkatan pada nilai post test atau post test lebih baik dari nilai pretest. Terjadi perbedaan signifikan antara nilai pretest dan posttest kemampuan komunikasi matematis siswa. Sebelum dilakukan program $\mathrm{CATCH}$ dan sesudah dilakukan program $\mathrm{CATCH}$ yaitu 0,000 .

\section{Pembahasan}

Temuan dan kajian beberapa faktor yang menjadi amatan selama penelitian berlangsung menjadi dasar pembahasan hasil penelitian pengembangan ini. Proses pembelajaran dengan program $\mathrm{CATCH}$ berbasis tutor sebaya yang terjadi di kelas, baik ketika siswa mengikuti bimbingan maupun pembelajaran tutor sebaya. Faktor yang menjadi amatan pada penelitian pengembangan ini adalah $S E$ dan kemampuan komunikasi matematis siswa pada pembelajaran matematika.

\section{SE Siswa pada Pembelajaran Matematika}

SE siswa dalam pembelajaran matematika merupakan salah satu bahan pengamatan pada penelitian ini. Hasil perolehan nilai SE siswa di awal dan akhir pembelajaran memberikan hasil yang baik. Hal ini 
menunjukkan bahwa terjadi peningkatan pada $S E$ siswa setelah menggunakan program $\mathrm{CATCH}$ berbasis tutor sebaya.

Perolehan rata-rata skor pretest SE menunjukkan pencapaian yang tergolong cukup efektif. Namun hasil tersebut tidak sebanding dengan hasil rata-rata skor komunikasi matematis, dimana dengan capaian rata-rata skor pretest SE dengan kategori cukup efektif tidak berbanding lurus dengan capaian rata-rata skor pretest kemampuan komunikasi matematis siswa. Berdasarkan fakta tersebut, dapat disimpulkan bahwa teori Bandura (1997) hanya berlaku untuk individu bukan kelompok karena uraian di atas dipengaruhi oleh faktor kemampuan siswa yang heterogen namun didominasi oleh siswa berkemampuan komunikasi matematis rendah, sehingga berakibat pada rendahnya rata-rata kelas. Proses tumbuhnya $S E$ siswa secara bertahap diamati oleh peneliti selama pembelajaran mulai dari pembelajaran pertama sampai kelima. SE dari 3 siswa belum mulai muncul pada pembelajaran pertama. Permasalahannya adalah ketiga tutee itu adalah 3 dari 10 siswa yang memilih teman sebaya pada urutan terakhir sehingga mereka mendapatkan tutor yang tidak sesuai dengan pilihannya. Akibatnya, timbul reaksi emosional dalam diri siswa yang mengakibatkan melemahnya SE dari ketiga siswa tersebut. Hal ini sesuai dengan teori Bandura (1994) yang menyebutkan bahwa kondisi fisik dan emosi akan memengaruhi kemampuan seseorang. Hal ini menandakan bahwa jika emosi seseorang tinggi maka akan mengubah kepercayaan diri seseorang terhadap kemampuannya.

Solusi untuk mengatasi permasalahan di atas dengan mengadakan pemilihan ulang teman sebaya. Strategi pemilihan tutor dilakukan dengan cara tutee menuliskan tutor yang dipilih pada kertas. Apabila terdapat tutor yang dipilih oleh lebih dari satu siswa, dibuat kesepakatan sampai masingmasing tutee menemukan tutor yang sesuai dengan harapannya untuk menghindari permasalahan yang sama. Teman sebaya hasil pemilihan kedua diberlakukan pada pertemuan kedua dan seterusnya. Dari hasil pengamatan, terlihat bahwa kegiatan diskusi berjalan lebih lancar. 
Kemudian pada kesempatan berikutnya, satu persatu dari tutee mulai berani maju kedepan untuk menuliskan jawaban penyelesaian soal dan mampu menjawab pertanyaan dari siswa maupun guru, semakin percaya diri, dan kemampuan komunikasi matematis pun semakin meningkat. Hal ini sesuai dengan teori Bandura yang menyatakan bahwa seseorang dengan $S E$ positif maka berpengaruh positif terhadap seseorang itu.

Peningkatan SE ini memiliki dampak positif terhadap hasil posttest kemampuan komunikasi matematis siswa. Jika pada awal pembelajaran tingkat $S E$ siswa tidak sebanding dengan hasil pretest kemampuan komunikasi matematis, maka pada akhir pembelajaran tingkat SE siswa sebanding dengan hasil posttest. Hal ini ditunjukkan oleh 17 siswa yang mencapai skor SE tinggi dan skor posttest kemampuan komunikasi matematisnya tinggi, seorang siswa mencapai skor $S E$ rendah dan skor posttestnya pun rendah. Sedangkan 2 siswa lainnya tidak demikian, mereka mencapai skor SE tinggi namun posttest kemampuan komunikasi matematisnya rendah atau kurang dari KKM. Faktor penyebabnya adalah siswa masih belum memahami materi fungsi secara maksimal atau tidak mengulang materi sebelum posttest dilaksanakan. Pada kasus ini, teori Bandura berlaku pada 18 siswa tetapi tidak untuk 2 siswa lainnya.

Perolehan skor SE secara umum mengalami peningkatan mulai dari awal sampai akhir pembelajaran. Hasil ini diikuti pula dengan peningkatan skor pretest dan posttest kemampuan komunikasi matematis siswa. Berdasarkan pengamatan dan catatan-catatan pada saat pembelajaran berlangsung, keberanian siswa bertanya kepada teman atau guru, menyatakan pendapat atau ide, menjawab atau menuliskan jawaban dengan benar, serta presentasi juga mengalami perubahan kearah yang lebih baik.

Temuan di lapangan memperlihatkan bahwa tutor yang memberikan bimbingan dengan pola komunikasi yang teratur, menghargai lawan bicara, dan bersifat memotivasi membuat tutee senang belajar, mampu mengikuti arahan dari tutor, menjadi yakin dalam 
menyelesaikan soal, dan percaya diri berani maju kedepan menuliskan jawaban maupun presentasi. Namun, tutor yang pola komunikasinya tidak teratur atau kurang baik maka yang terjadi adalah tutee lebih lama memahami materi, kurang berani serta bingung dalam menyelesaikan soal. Dari temuan tersebut, diketahui bahwa dengan pola interaksi yang baik berdampak pada SE dan komunikasi matematis yang baik pula. Kondisi ini sesuai dengan teori belajar konsruktivisme Vigotsky (Danoebroto, 2015) yang menyatakan perkembangan kognitif siswa akan semakin terbentuk karena adanya interaksi sosial dengan siswa lain.

Pembelajaran menggunakan program $\mathrm{CATCH}$ berbasis tutor sebaya secara umum memberikan hasil yang positif pada SE siswa. Hal ini didasarkan pada pengalaman yang dimiliki siswa, siswa akan memiliki keyakinan tinggi dalam menyelesaikan uji kompetensi secara individu setelah mendapat bimbingan dari tutor pada saat melakukan kegiatan tutor sebaya.

\section{Kemampuan Komunikasi Matematis Siswa pada Pembelajaran Matematika}

Berdasarkan hasil analisis data diketahui bahwa terjadi peningkatan kemampuan komunikasi matematis siswa yang terjadi setelah melaksanakan pembelajaran matematika menggunakan program $\mathrm{CATCH}$. Artinya, pengembangan program $\mathrm{CATCH}$ berbasis tutor sebaya efektif meningkatkan $S E$ dan kemampuan komunikasi matematis siswa. Hal ini juga dapat dilihat pada pencapaian indikator kemampuan komunikasi matematis siswa yang meningkat setelah menggunakan produk yang dikembangkan.

Hasil pretest kemampuan komunikasi matematis menunjukkan bahwa dari 20 siswa tidak ada yang mendapatkan nilai di atas KKM. Pencapaian indikator komunikasi matematis pada pretest masih sangat rendah. Rata-rata pencapaian skor pretest pada indikator kemampuan siswa dalam menjelaskan ide, situasi, dan relasi matematika secara tulisan 
masih tergolong rendah, namun rata-rata pencapaian skor pada indikator kemampuan menggambar, meliputi menggambar situasi masalah dan menyatakan solusi masalah, diagram, gambar, tabel, lebih baik dari indikator pertama namun tergolong kurang. Diantara ketiga indikator, pencapaian indikator ketiga yaitu kemampuan siswa dalam membuat ekspresi matematis adalah yang paling rendah. Pencapaian hasil pretest tidak jauh dari pencapaian posttest. Pencapaian indikator komunikasi matematis pada posttest mengalami peningkatan dari hasil pretest. Ratarata pencapaian skor posttest pada indikator kedua lebih baik dari pencapaian indikator pertama.

Namun, pencapaian indikator ketiga masih berada di posisi paling akhir artinya paling rendah tetapi masih tergolong baik. Hal ini terjadi karena siswa kurang memahami maksud simbol-simbol yang terdapat pada soal-soal materi fungsi, seperti $\leq, \geq,\rangle,\langle, \epsilon, \rightarrow$, dan I. Berdasarkan hasil pengamatan, beberapa siswa mengalami kesulitan menggunakan dan membedakan simbol-simbol yang ada pada kalimat matematika. Padahal menurut Hulukati (2005) jika siswa tidak dapat berkomunikasi dengan baik dalam memaknai permasalahan maupun mengekspresikan masalah secara matematis, ia tidak dapat menyelesaikan masalah tersebut dengan baik.

Pembelajaran menggunakan program $\mathrm{CATCH}$ berbasis tutor sebaya memberikan dampak positif bagi perkembangan kemampuan komunikasi matematis siswa. Kemampuan ini semakin meningkat seiring dengan seringnya siswa mendapat bimbingan dari tutor. Kemampuan siswa meningkat ketika diminta menyatakan solusi masalah dalam bentuk diagram.

Temuan pada penelitian ini adalah terdapat 2 siswa yang memperoleh skor posttest SE tinggi tetapi skor posttest kemampuan komunikasi matematisnya di bawah KKM meskipun nilai tersebut meningkat dari nilai pretestnya. Hal ini menimbulkan pertanyaan karena jika dikaitkan dengan pendapat Hamidah (2014) yang menyebutkan bahwa 
kemampuan komunikasi matematis seseorang akan meningkat apabila mampu memunculkan SE dalam dirinya, tidak memenuhi. Kemudian peneliti mewawancarai kedua siswa dan diperoleh jawaban bahwa siswa terbiasa menyelesaikan soal dengan bimbingan teman sehingga ketika mengerjakan posttest secara individu siswa tersebut kembali bingung dengan langkah-langkah penyelesaiannya apalagi ketika diminta mencari rumus suatu fungsi. Temuan ini didukung dengan teori pembelajaran konstruktivisme Vygotsky (Danoebroto, 2013) dimana siswa tidak akan kesulitan memahami matematika yang abstrak, jika didorong melalui fasilitator seperti guru atau teman sebaya dengan ZPD (Zone of Proximal Development). Artinya bahwa memasukkan metode tutor sebaya kedalam program $\mathrm{CATCH}$ menjadi jembatan bagi siswa dalam memecahkan masalah matematika.

Temuan lainnya, terdapat 2 siswa yang memiliki skor posttest $S E$ rendah, tetapi skor posttest komunikasi matematisnya 100. Dari fakta tersebut disimpulkan bahwa kedua siswa selain memiliki kemampuan komunikasi matematis dan sikap empati yang baik. Temuan ini jika dikaitkan dengan teori Multiple Intelligences oleh Gardner (Santrock, 2011) menunjukkan bahwa kedua siswa memiliki kemampuan matematis dan kecerdasan interpersonal yang salah satunya ditunjukkan dengan cara berempati kepada siswa lain.

Penggunaan program $\mathrm{CATCH}$ terhadap kemampuan komunikasi matematis siswa dianalisis secara deskriptif dan statistik. Dari pengujian secara deskriptif maupun statistik menunjukkan hasil yang sama, yakni terjadinya peningkatan kemampuan komunikasi matematis siswa yang tergolong tinggi setelah diberikan program $\mathrm{CATCH}$ atau dengan kata lain penggunaan program $\mathrm{CATCH}$ adalah efektif dalam meningkatkan kemampuan komunikasi matematis siswa. Program $\mathrm{CATCH}$ selain mampu meningkatkan $S E$ dan kemampuan komunikasi matematis siswa juga banyak diminati siswa, sebagian besar siswa (70\%) menyatakan sangat setuju terhadap program $\mathrm{CATCH}$ dan siswa lainnya menyatakan 
setuju. Hal ini menunjukkan bahwa seluruh siswa memberikan respon positif terhadap pelaksanaan program $\mathrm{CATCH}$. Hasil survey ini sekaligus mendukung hasil pengukuran keefektifan program $\mathrm{CATCH}$ sebelumnya.

\section{Penutup}

Kesimpulan yang didapat dari hasil penelitian ini antara lain program $\mathrm{CATCH}$ berbasis tutor sebaya yang telah dilakukan melalui tahapan pra-pengembangan, pengembangan, dan paska pengembangan telah memenuhi standar kelayakan oleh uji ahli materi, ahli desain, dan ahli bahasa. Peningkatan SE siswa setelah diberikan pembelajaran menggunakan pengembangan program $\mathrm{CATCH}$ berbasis tutor sebaya termasuk dalam kategori efektif. Hal ini didasarkan pada hasil uji deskriptif dengan $\mathrm{N}$-Gain dan uji statistik dengan uji t terhadap skor angket $S E$ sebelum dan sesudah diberikan pengembangan program CATCH. Peningkatan kemampuan komunikasi matematis siswa setelah diberikan pengembangan program $\mathrm{CATCH}$ berbasis tutor sebaya termasuk dalam kategori sangat efektif. Hal ini didasarkan pada hasil uji deskriptif dengan $\mathrm{N}$-Gain dan uji statistik dengan uji t terhadap skor pretest dan posttest.

Temuan menarik dalam penelitian ini, diantaranya bahwa pola interaksi sosial tutor yang tercipta pada program $\mathrm{CATCH}$ berbasis tutor sebaya secara langsung mampu meningkatkan kemampuan komunikasi matematis siswa. Teori yang mendukung temuan ini adalah teori konstruktivisme aliran Vigotsky. Temuan lainnya, yaitu munculnya kecerdasan interpersonal dalam diri siswa pada saat mengembangkan $S E$ mereka. Teori yang mendukung adalah teori multiple intelligences dari Gardner.

Berdasarkan hasil kesimpulan ini dapat dinyatakan bahwa penelitian ini dapat dikembangkan dengan memadukan beberapa model atau metode 
pembelajaran dengan memperhatikan pada kemampuan kognitif siswa dan diperlukan waktu yang lebih lama untuk melihat $S E$ siswa. Ini dikarenakan untuk membiasakan siswa dengan SE positif membutuhkan waktu yang lama.

\section{Ucapan Terima Kasih}

Penulis menghaturkan terima kasih sebesar-besarnya kepada pihak-pihak tertentu yang telah memberikan dukungan sehingga artikel ini dapat terselesaikan dengan baik. Harapan penulis, semoga artikel ini bermanfaat bagi diri penulis khususnya dan dapat menambah referensi dalam dunia pendidikan.

\section{Daftar Referensi}

Ahmadi, A dan Supriyono, W. (2004). Psikologi Belajar. Jakarta: Rineka Cipta.

Akker, J. (2006). Educational Design Research. London and New York: Routledge.

Ansari. (2009). Komunikasi Matematik. Banda Aceh: Yayasan Pena.

Arikunto, S. (1999). Prosedur Penelitian: Suatu Pendekatan Praktek. ed. Rev. IV. Yogyakarta: Rineka Cipta.

Arikunto, S. (2013). Manajemen Penelitian. Jakarta: Rineka Cipta.

Badri, M., Lubis, D., Susanto, D., \& Suharjito, D. (2018). Communication Risk of Stakeholders in Preventing Forest and Land Fires in Riau Province. Jurnal Ilmiah Peuradeun, 6(2), 179-198. doi:10.26811/peuradeun.v6i2.222

Bandura, A. (1977). Self-Efficacy: Toward a Unifyng Theory of Behavioral Change. Psicologycal Review. Stanford University: Vol. 84, No.2, P. 191-215.

Bandura, A. (1994). Self Efficacy. In V.S. Ramachaudran (Ed). Encyclopedia of Human Behavior (Vol. 4, pp. 71-81). New York: Academic Press. (Reprinted in H. Friedman [Ed.], Encyclopedia of Mental Health. San Diego: Academic Press, 1998).

Danoebroto, S W. (2015). Teori Belajar Konstruktivis Piaget dan Vigotsky. Indonesian Digital Journal of Mathematics and Education Volume 2 
Nomor 3 Tahun 2015. http://idealmathedu.p4tkmatematika.org: ISSN 2407-7925. Publikasi: 7 Januari 2016.

Departemen Pendidikan Nasional. (2002). Teknik Belajar dengan Modul, Jakarta: Dirjen Pendidikan Dasar dan Menengah.

Depdiknas. (2006) Standar Kompetensi Mata Pelajaran Matematika SMP/ MTS. Jakarta: Depdiknas.

Hake, R. (1999). Analizing Change/ Gain Scores. [online]. http://www.physics. Indiana.edu. [13 Juli 2016].

Hamidah. (2014). Pengaruh Self Efficacy Terhadap Kemampuan Komunikasi Matematik. Seminar Nasional Pendidikan Matematika FMIPA. Universitas Negeri Yogyakarta. http://seminaruny.ac.id. 26 Juli 2016].

Hulukati, E. (2005). Mengembangkan Kemampuan Komunikasi dan Pemecahan Masalah Matematik Siswa SMP Melalui Model Pembelajaran Generatif. Disertasi. Program Pascasarjana: Digilib.upi.edu. Publikasi: 07 Januari 2013.

Karolina, C., Maryani, E., \& Sjuchro, D. (2020). The Communication Competence of Visual Reader at Visually Impaired's Cinema. Jurnal Ilmiah Peuradeun, 8(2), 225-242. doi:10.26811/peuradeun.v8i2.488

National Council of Teachers of Mathematics. (2000). Executive Summary Principles and Standards for School Mathematics. www.nctm.org.pdf: [21 Juli 2016].

Nguyen, M. (2013). Peer Tutoring as a Strategy to Promote Academic Success. Research Brief: Duke University.

Pakpahan, H L. (2014). Analisis Self-Efficacy dan Kesalahan dalam Mengerjakan Soal Pemalaran Matematis Siswa SMA. Program Pascasarjana Pendidikan Matematika Universitas Pendidikan Indonesia. Bandung.

Permendikbud Nomor 81 A tahun 2013 tentang Implementasi Kurikulum 2013. Menteri Pendidikan dan Kebudayaan Republik Indonesia.

Permendiknas Nomor 22 Tahun 2006 tentang Standar Isi Untuk Satuan Pendidikan Dasar dan Menengah. Menteri Pendidikan Nasional Republik Indonesia. 
Provasnik. (2016). Highlights From TIMSS and TIMSS Advanced 2015. Page 5-9. National Center for Education Statistics. Institute od Education Sciences. US Department of Education

Raditiana dan Yorni. (2013). Pengembangan Model Peer Guidance untuk Meningkatkan Self Efficacy Siswa Kelas VIII H SMP Negeri 2 Salatiga. http://repository.uksw.edu/handle/123456789/3572. [11 Juni 2016].

Roscoe, Chi. (2007). Tutor Learning: The Role of Explaining and Responding to Questions. Springer Science Business Media B.V. 2007. [13 April 2015].

Ruseno dan Titin. (2010). Metode Pembelajaran Tutor Teman Sebaya Meningkatkan Hasil Belajar Berdasarkan Regulasi Diri. Makara, Sosial Humaniora Vol. 14, No.2, 91 - 97.

Schunck dan Pajares. (2002). The Development of Academic Self-Efficacy: Chapter in A Wigfield \& J. Eccles (Eds). Development of Achievement Motivation. San Diego: Academic Press. LAEB Room 5108. Purdue University. dschunk@purdue.edu. [28 April 2016].

Sudrajat. (2012). Permendiknas RI Nomor 23 Tahun 2006. [Online]. http://akhmad sudrajat.files.wordpress.com/2012/01/nomor-23-tahun2006. pdf. [1April 2016].

Tessemer. (1993). Planning and Conducting Formative Evaluations: Improving the Quality of Education and Training. London and New York: Routledge.

The SEA Program: Model of Esteem. (2004). The Tool of Coping Series and the SEA's Program Recovery. [Online]. http://www.esteem.model.htm. [17 Juli 2016].

Zulkosky, K. (2009). Self-Efficacy: A Concept Analysis. http://www.onlinelibrary.wiley.com. Volume 44, Issue 2. Publikasi: April 2009. [12 Agustus 2016]. 